\title{
Effect of gender differences on job satisfaction of the female employees in Pakistan
}

\author{
Nayab Fatima ${ }^{1}$, Shahid Iqbal ${ }^{1}$, Sadaf Younis Akhwand ${ }^{1}$, Muhammad Suleman ${ }^{1}$, \\ Muhammad Ibrahim ${ }^{2}$ \\ ${ }^{1}$ Department of Business Administration Bahaudin Zakria University, Multan, Punjab, Pakistan \\ ${ }^{2}$ Center for Emerging Sciences Engineering and Technology, Islamabad, Pakistan
}

\section{Email address:}

mishaalkhan892@yahoo.com (N. Fatima), shahid_khosa786@yahoo.com (S. Iqbal), sweet.sabeera@gmail.com (S. Y. Akhwand), msulman.khan@yahoo.com (M. Suleman),ibrahimkhanleghari@yahoo.com (M. Ibrahim)

\section{To cite this article:}

Nayab Fatima, Shahid Iqbal, Sadaf Younis Akhwand, Muhammad Suleman, Muhammad Ibrahim. Effect of Gender Differences on Job Satisfaction of the Female Employees in Pakistan. International Journal of Economics, Finance and Management Sciences. Vol. 3, No. 1, 2015, pp. 27-33. doi: 10.11648/j.ijefm.20150301.14

\begin{abstract}
The objective of this research is to further determine the gender differences while controlling the effect of selected variables on job satisfaction using data gathered from employees working in the Non-Governmental Organizations (NGOs) and public sector schools of selected Districts of Southern Punjab. This research was based on primary data which was collected from 90 employees (45 females and 45 males) working with the Ngo's and Schools. The research results showed that there is a positive significant relationship between selected independent variables with dependent variable. The research results also indicated that in Pakistan, male employees are more satisfied with their jobs as compared to female employees. This study is helpful for management to revise their policies to eliminate the differences of job benefits for males and females in order to increase the job satisfaction of female employees.
\end{abstract}

Keywords: Gender, Job Condition, Management Condition, Personal Fulfillment, Using Ability in the Job

\section{Introduction}

Gender has strong impact on the job satisfaction of the employees of the organizations. In Pakistan, our society behavior shows that males have upper hand on their families as well as in organization they have the superior power .Our society exploits the women entity and they have no power even they cannot speak loudly in the presence of their men. Female employees are usually face many problems in the organizations as compared with male employees due to several challenges and barriers, these barriers include forgoing marriage, motherhood, discrimination prevents the female employees to work in the organizations. Females who are highly qualified, cannot reach administrative rank in the organizations (Li and Leung, 2001). Female employees cannot work for long hours in the organization and cannot move from one place to another (Pinar et al., 2011). In the organizations female employees get fewer opportunities for promotion that is important to fulfill the expectations of female's employees, (McCuddy et al., 2010).

Employees leave the organization just because of long working hours and poor working environment (Kusluvan and kusluvan, 2000). Dissatisfied employees leave their position in the organization as compared to those employees who are satisfied (G Liselli et al., 2001) Male and female employees dislike their job in the organization just because of long working hours, job stress, low income, no time for their personal life, shortage of labour, lack of employee motivation and the attitudes between the employees and managers (Pavesic and Brymer, 1990). Okumus et al. (2010) also find out that female employees have not enough time for their friends and family, and for hobbies, face difficulties for promotion, long working hours and job conditions and not having time for household duties were the problems for female employees.

Given the many correlates and consequences of employee's satisfaction in the organization, the purpose of this study is to analyze gender differences with regard to employee satisfaction.

\subsection{Research Gap}

This current study controls for a number of demographic 
variables and also drills down to examine specific dimensions of employee satisfaction construct in order to shed new light on the theoretical and managerial topic area. By controlling for a select number of variables, it is hoped that inconsistent findings on gender difference could be minimized and move detailed information can be revealed on gender difference.

\subsection{Problem Statement}

We are trying to highlight the problems that female employees are now facing in the organizations. Female employees are treated unfairly as compare to male employees. Because organizations do not allow the female employees to take part in the decision making process. Because they think that female employees are panic and cannot perform better than the male employees. That's why Male employees are more satisfied with their jobs \& organizations give promotion only to male employees. The purpose is to resolve these problems.

\subsection{Research Questions}

This research, Effect of Gender Differences on Job Satisfaction of the Female Employees in Pakistan has been taken in account with following specific research questions:

- How the job conditions effect the employees in order to achieve job satisfaction?

- What is the role of management condition to attain job satisfaction?

- What are the main contributions of personal fulfillment on job satisfaction?

- How this research will contribute to resolve the issue of different benefits for female and male?

\subsection{Managerial Implications}

With respect to practical implications, the result of this study can be used as guideline for organizations (Ngo's \& schools) to increase the job satisfaction of female employees. If Organizations provide equal opportunities, fair salaries, provide incentives and treat them equally then it may be possible that females can perform better and satisfied jobs as compared to male employees.

\subsection{Research Objectives}

The objective of this research was to know the effect of gender differences on job satisfaction of the female employees in Pakistan with the specific aim of:

- To develop the theoretical frame work after literature reviewed

- To know the impact of unequal job benefits on job satisfaction of female employee

- To evaluate the effect of management conditions on job satisfaction

- To investigate the impact of personal fulfilment on job satisfaction

- To investigate the impact of using ability in job on job satisfaction

\section{Literature Review}

Consequently, a woman's want for progress into a seniorlevel leadership position becomes more difficult because of the dominant "old-style role" assumptions (Schaap et al., 2008).Also, research conducted in the US indicates that, even in America, uneven low number of highly educated females achieve executive prestige in the industry ( $\mathrm{Li}$ and Leung, 2001). In the hospitality and tourism sectors around the world, and in numerous arrangements, these obstacle and tests discourage female employees from continuing their professional careers in the hospitality industry for fear of intervention with their secretive and societal lives. The organization therefore, provides less occasions for advancement that are satisfactory to meet the potentials of females (McCuddy et al., 2010).

Pervious study shows that, the many connections and moments of employee satisfaction in the hospitality sector, investigated the possible gender variances with respect to employee satisfaction. This study is necessary because, as will be comprehensive in the upcoming sectors, there presently be real an extensive range of unpredictable results in the literature with respect to this clash. This modern study controls for a number of demographic variables and also drills-down to survey exact scopes of the employee satisfaction hypothesis in direction to explore new world on the hypothetically and organizationally important theme area. By monitoring for a select quantity of variables, it is expected that varying discoveries on gender differences could be reduced and more comprehensive information can be exposed on gender variances. The existing study is planned to statement employee job satisfaction using data from Pakistani organization. Study shows that, Contracted the major incidence of women in labor force, it is actual significant that we recognize the fundamentals of job satisfaction, mostly using a gendered perspective (GarciaBernal et al., 2005).research shows that, In the hospitality industry, like in many other industries, employees' decision about their labor force involvement depends on job satisfaction. So, analysis of job satisfaction may offer insight into employees' observations of certain sides of the nature of the organization (Clark, 1996). Previously data shows that, there are some unique aspects of managing in the hospitality and tourism sector that make the process of hiring and maintaining employees difficult. These sides, which add to high takings rates, may include: labor intensiveness, weak internal labor markets, 24/7-52weeks a year operation, low status and gender structure (mostly female), and a low level of professional esteem (Burke et al., 2008a).

Determining the perceptions of employees about their tourism industry is significant for considerate what instruments lead to employees' approaches and actions toward their job (Tuzun, 2009). The tourism industry is an industry its offers a wide variety of jobs with a range of human capital necessities (Szivas et al., 2003). Organizational commitment and job satisfaction can be interpreted to propose that a high quantity of reciprocity 
exists between the individual and the organization (Ryanet al., 2011). If employees are satisfied with their jobs, they feel powerfully motivated to reinstate good working situation and may also feel hopeful about the possibilities for development. Previous researchers found that high job satisfaction is evidence by employee loyalty such as good citizenship performance (Rusbult et al., 1988). Essentially, these positive outcomes narrate to satisfied employee's representative high level of organizational pledge (Yang, 2010). That is, Pettijohn et al. (2004) found that job satisfaction is positively related to the customer orientation scores. Their finding supports the disagreement that satisfied employees are either more competent of engaging in escalating customer satisfaction (Pettijohn et al., 2004). Research shows that,, employees who are dissatisfied with their job are more probable to leave their place than those are satisfied (Ghiselli et al., 2001). Such an association between customer satisfaction and employee satisfaction is sometimes term "the satisfaction mirror" in which the satisfaction of both groups of constituent provide for each other (Noe et al., 2010).

Job satisfaction is how content an individual is with his or her job. Previously, Scholars and human resource professionals generally make a discrepancy between affective job satisfaction and intellectual job satisfaction. Affective job satisfaction is the amount of pleasant emotional state of mind individuals have about their jobs overall, and is different to intellectual job satisfaction which is the extent of individuals' satisfaction with particular facets of their jobs, such as pay, pension arrangements, working hours, and numerous other characteristics of their jobs. Researcher said that, Understanding what stimulate job satisfaction is one of the most significant issue for organizations in human resource management. Study said that,Job satisfaction is strong-minded not only by the employees' objective working state of affairs, but also by their subjective perceptions about their job (Mora and Ferrer-i-Carbonell, 2009).

Researcher,Locke (1969) defines job satisfaction as an agreeable emotional state ensuing from the employee appraises his/her job as achieving and/or facilitating their own job principles (Locke, 1969). Job satisfaction is based on assessment of circumstances that survive on the job (work load, appropriate supervision) and/or financial outcomes from the job (pay, security). Job satisfaction consists of filtered and processed perceptions; filtered through the individual's system of norms, principles, and prospect (Schneider and Snyder, 1975).Group of researchers, Jung et al. (2007) reported that job satisfaction is connected to employees' prospect and realities. Specifically, aggravated and dissatisfied employees are likely to have a low-level of job satisfaction. These prospect and realities may also vary according to age, education, gender, and cultural setting. These features can be important factors of job satisfaction (Jung et al., 2007). Spector (1997)summarized job satisfaction determinants such as approval, communication, co-workers, tassel benefits, job conditions, environment of the work itself, the nature of the organization itself, an organization's policies and measures, pay, personal growth, endorsement opportunities, credit, security and management (Spector, 1997).

Previously researcher studied the association between gender and job satisfaction examined regularly. As before confirmed, the main inducement of the current study is to address the contradictory findings reported in the literature concerning gender differences regarding job satisfaction. The findings about gender differences related to job satisfaction have been not in agreement from the 1950s to date (Al-Ajmi, 2006). For example, some studies (e.g. Mora and Ferrer-iCarbonell, 2009) find that males show more satisfaction in their job than females. Yet, other studies (Okpara et al., 2005; Clark, 1997; Kim, 2005; Jung et al., 2007) indicate that females have more satisfaction than males. While yet other studies (Linz, 2003; Koyuncu et al., 2004; Eskildsen et al., 2004; Al-Ajmi, 2006; Frye and Mount, 2007; Ward and Sloane, 2000) find no significant gender differences in job satisfaction. The current study, so, control for a number of demographic variables and also drills-down to observe specific volume of the employee satisfaction build.

\section{Theoretical Frame Work}



Figure 1. theoretical frame work 
The theoretical frame is drawn after deep review of literatures, this theoretical frame work shows a specific relationship between independent variables and dependent variables and formulation of hypothesis. In this research Management condition, Personal fulfillment and Using ability in job has been taken as independent variables and job satisfaction as a dependent variable. For this research after the deep study of literature following hypothesis has been proposed.

H1: There is a positive relationship between Gender and Job Conditions.

H2: There is a positive relationship between Gender and Personal Fulfillment.

H3: There is a positive relationship between Gender and Using Ability in the Job.

\section{Research Methodology}

The objective of this research is to determine gender differences while controlling the effect of selected variables on job satisfaction using data gathered from male and female employees in the Ngo's and male and female teachers of public sector schools.

\subsection{Population \& Sample}

We conducted our research in selected Districts of Southern Punjab (Dera Ghazi Khan, Rajanpur and Layyah Districts) because there are many Ngo's like Tribal Area Development Program, NRSP (National Rural Support Program), Al Asar Development Organization, Concept Development Services and Himet Development Organization. There are also many public sector schools in these Districts. The sample size was 100 male and female employees working in these organizations. The 90 accurately filled questionnaires were used for this research.

\subsection{Time Dimension}

In our research, we used the cross sectional technique for collecting the data. We collected data from Ngo's and public sector schools at once.

\subsection{Questionnaire}

The questionnaire consisted of two parts. First part of the questionnaire is about gender, level of education and marital status. Second part is about Job Satisfaction, management condition, personal fulfillment \& using ability in the job. For measuring the job satisfaction of employees in Ngo's, questionnaire was adopted by (Weiss et al., 1967). To measuring the job satisfaction of teachers working in schools, we brought some changes in the adopted questionnaire. The likert scale was used for this purpose, and took 19 questions for measuring the job satisfaction of males and females employees working in Ngo's and schools. The range of likert scale was composed from 1-5, 1 for strongly agree, 2 for agree, 3 for neutral, 4 for strongly disagree and 5 for disagree.

\subsection{Procedure}

Procedures we used for data analysis contain factor analysis, descriptive analysis, reliability analysis, and correlation analysis between variables. We used these statistical tools in our research to analyze the questionnaire items.

\section{Results}

\subsection{Demographic Analysis}

Table 1. Demographic Analysis

\begin{tabular}{|c|c|c|c|c|c|}
\hline \multicolumn{6}{|c|}{ GENDER } \\
\hline & & Frequency & Percent & Valid Percent & $\begin{array}{l}\text { Cumulative } \\
\text { Percent }\end{array}$ \\
\hline \multirow{3}{*}{ Valid } & 1.00 & 45 & 50.0 & 50.0 & 50.0 \\
\hline & 2.00 & 45 & 50.0 & 50.0 & 100.0 \\
\hline & Total & 90 & 100.0 & 100.0 & \\
\hline
\end{tabular}

Total 100 questionnaires were distributed between the employees of Ngo's and the teachers of schools. The questionnaires were distributed in equal percentage of $50 \%$ for male and $50 \%$ for female respondents. The accurate responses received were 90 responses.

\subsection{Material Status}

Table 2. material status

\begin{tabular}{llllll}
\hline Marital Status & & & & \\
\hline & & Frequency & Percent & $\begin{array}{l}\text { Valid } \\
\text { Percent }\end{array}$ & $\begin{array}{l}\text { Cumulative } \\
\text { Percent }\end{array}$ \\
\hline \multirow{4}{*}{ Valid } & Married & 75 & 83.3 & 83.3 & 83.3 \\
& Single & 15 & 16.7 & 16.7 & 100.0 \\
& Total & 90 & 100.0 & 100.0 & \\
\hline
\end{tabular}

In this research $83.3 \%$ respondents were married employees and $16.7 \%$ were unmarried.

\subsection{Level of Education}

Table 3. level of education

\begin{tabular}{llllll}
\hline & & $\begin{array}{l}\text { Frequenc } \\
\mathbf{y}\end{array}$ & Percent & $\begin{array}{l}\text { Valid } \\
\text { Percent }\end{array}$ & $\begin{array}{l}\text { Cumulative } \\
\text { Percent }\end{array}$ \\
\hline \multirow{4}{*}{ Valid } & 1.00 & 1 & 1.1 & 1.1 & 1.1 \\
& 2.00 & 26 & 28.9 & 28.9 & 30.0 \\
& 3.00 & 63 & 70.0 & 70.0 & 100.0 \\
& Total & 90 & 100.0 & 100.0 & \\
\hline
\end{tabular}

$1.1 \%$ under graduate teachers and employees, $28.9 \%$ graduate teachers and employees and $70 \%$ post graduate teachers and employees show their interest and gave responses.

\subsection{Reliability Analysis}

The value of Cronbach's Alpha of all variables is 0.815 which shows that items used in the questionnaire are highly reliable. The questionnaire can predict research results. 


\subsection{Descriptive Statistics}

Table 4. Descriptive statistics

\begin{tabular}{llllll}
\hline & N & Minimum & Maximum & Mean & $\begin{array}{l}\text { Std. } \\
\text { Deviation }\end{array}$ \\
\hline MC & 90 & 2.60 & 5.00 & 4.1089 & .64732 \\
PF & 90 & 2.80 & 5.00 & 4.1244 & .52581 \\
UAJ & 90 & 2.40 & 5.00 & 4.0467 & .53970 \\
JC & 90 & 2.00 & 5.00 & 3.9667 & .72786 \\
Valid N & 90 & & & & \\
(listwise) & & & & & \\
\hline
\end{tabular}

The descriptive analysis shows that the mean of management condition is 4.1089 and standard deviation is 0.64732 , the mean of personal fulfillment is 4.1244 and standard deviation is 0.52581 . Similarly the mean of using ability in the job is 4.0467 and standard deviation is 0.53970 and mean of job satisfaction is 3.9667 and standard deviation is 0.72786 .

\subsection{Descriptive Analysis}

Table 5. descriptive analysis

\begin{tabular}{|c|c|c|c|c|c|c|}
\hline \multicolumn{7}{|c|}{ Descriptive Statistics } \\
\hline \multicolumn{2}{|c|}{ GENDER } & $\mathbf{N}$ & Minimum & Maximum & Mean & $\begin{array}{l}\text { Std. } \\
\text { Deviation }\end{array}$ \\
\hline \multirow{5}{*}{ Male } & $\mathrm{MC}$ & 45 & 3.00 & 5.00 & 4.3022 & .55041 \\
\hline & $\mathrm{PF}$ & 45 & 3.20 & 5.00 & 4.3022 & .50744 \\
\hline & UAJ & 45 & 3.40 & 5.00 & 4.2533 & .46982 \\
\hline & $\mathrm{JC}$ & 45 & 2.75 & 5.00 & 4.2111 & .59102 \\
\hline & $\begin{array}{l}\text { Valid N } \\
\text { (listwise) }\end{array}$ & 45 & & & & \\
\hline \multirow{5}{*}{ Female } & $\mathrm{MC}$ & 45 & 2.60 & 5.00 & 3.9156 & .68422 \\
\hline & $\mathrm{PF}$ & 45 & 2.80 & 5.00 & 3.9467 & .48692 \\
\hline & UAJ & 45 & 2.40 & 5.00 & 3.8400 & .53018 \\
\hline & $\mathrm{JC}$ & 45 & 2.00 & 5.00 & 3.7222 & .77464 \\
\hline & $\begin{array}{l}\text { Valid N } \\
\text { (list wise) }\end{array}$ & 45 & & & & \\
\hline
\end{tabular}

Criteria for male: 4.25 closely related to strongly agree.

Criteria for females: 3.25 closely related to agree.

Through descriptive statistics, we came to know that males are more satisfied with management condition, personal fulfillment and using ability in the job which are above the stated criteria that is 4.25 . But males are relatively low satisfied with job conditions which are below the stated criteria. Through descriptive statistics, we came to know that females are agreed with management condition, personal fulfillment, using ability in the job and job condition. But females are less satisfied as compared to males.

\subsection{Correlation Analysis}

The correlation analysis shows that there is low correlation between Management condition (MC) and Job satisfaction as the correlation value of $\mathrm{MC}=0.420 * *$. The resulted correlation value for Personal fulfillment (PF) is $0.410 * *$ which shows the low correlation with job satisfaction. It also has seen low correlation between Using ability in job (UAJ) and job satisfaction as the research result of correlation for $\mathrm{UAJ}$ is $0.446^{* *}$.
Table 6. Correlations analysis

\begin{tabular}{llllll}
\hline \multicolumn{2}{l}{ Correlations } & MC & PF & UAJ & JS \\
\hline MC & Pearson Correlation & 1 & & & \\
PF & Pearson Correlation & $.505^{* *}$ & 1 & & \\
UAJ & Pearson Correlation & $.349^{* *}$ & $.355^{* *}$ & 1 & \\
JS & Pearson Correlation & $.420^{* *}$ & $.410^{* *}$ & $.446^{* *}$ & 1 \\
\hline
\end{tabular}

Low correlation between .3 and .5

Medium correlation between .5 and .7

High correlation above .7

\section{Discussion}

The findings of our research show that gender differences directly affect job satisfaction of female employees. To measure job satisfaction we used job three variables as dependent like management condition, personal fulfillment and using ability in the job. The result of statistical data shows that males are more satisfied with management condition, personal fulfillment and using ability in the job but least satisfied with job conditions. But females are less satisfied as compared to males on the basis of criteria (3.25). All above hypotheses are accepted.

\section{Conclusion}

The basic aim of this research was to further know the effect of gender differences on job satisfaction of the female employees in Pakistan. The research results of this research showed that there is a positive relationship between gender and job satisfaction. On the basis of result we can say that females are less satisfied with their jobs as compared to male employees, because in Pakistan, there is man dominated society. Females have less chance for advancement. In Pakistan normally organization gives importance to male employees for executive status. Because they think that females are not eligible for executive post due to having low decision power and confident. Though this men dominant societies become huge hurdle in the way of females professional careers.

\section{Limitations and Future Directions}

We used quantitative technique in our research and obtain 90 responses from males and female employees in Ngo's and in schools. Mostly employees are post graduated and married. We took management condition, personal fulfillment, using ability in the job as independent variable and job condition as dependent variable. This research is done in D.G Khan, Rajanpur and Layyah District and used the sample of Ngo's and Schools. This study provides some suggestions for future studies. We can take psychological climate as mediating variable and supervisor involvement as moderating variable and organizational commitment. We can apply this model also in other sectors like small industries, universities, banking and in hospital sectors for measuring the job satisfaction of female employees. 


\section{References}

[1] Al-Ajmi, R. (2006). "The effect of gender on job satisfaction and organizational commitment in Kuwait". International Journal of Management. Vol. 23 No. 4. pp. 838-943.

[2] Burke, R., Koyuncu, M. and Fiksenbaum, L. (2008a). "Work experiences, satisfactions and Psychological well-being of female and male managers in the hospitality sector in Turkey". Equal Opportunities International. Vol. 27 No. 6. pp. 505-18.

[3] Burke, R., Matthiesen, S., Einarsen, S., Fiskenbaum, L. and Soiland, V. (2008b). "Gender differences in work experiences and satisfactions of Norwegian oil rig workers".Gender in Management: An International Journal. Vol. 23 No. 2.pp. 137-47.

[4] Clark, A. (1996). "Job satisfaction in Britain". British Journal of Industrial Relations. Vol. 34 No. 2. pp. 189-217.

[5] Eskildsen, J., Kristensen, K. and Westlund, A. (2004). "Work motivation and job satisfaction in the Nordic countries". Employee Relations. Vol. 26 Nos 1/2. pp. 122-36.

[6] Frye, W. and Mount, D. (2007).“An examination of job satisfaction of general managers based on hotel size and service type". Journal of Human Resources in Hospitality \& Tourism. Vol. 6 No. 2. pp. 109-34.

[7] Garcia-Bernal, J., Gargallo-Castel, A., Marzo-Navarro, M. and Rivera-Torres, P. (2005). "Job satisfaction: empirical evidence of gender differences". Women in Management Review, Vol. $20 \mathrm{Nos} 3 / 4$. pp. 279-88.

[8] Ghiselli, R., La Lopa, J. and Bai, B. (2001). "Job satisfaction, life satisfaction, and turnover intent among food-service managers". Cornell Hotel and Restaurant Administration Quarterly. Vol. 42 No. 2. pp. 28-37.

[9] Jung, K., Jae Moon, M. and Hahm, S.D. (2007). "Do age, gender, and sector affect job satisfaction? Results from the Korean labor and income panel data". Review of Public Personnel Administration. Vol. 27 No. 2. p. 125.

[10] Kim, S. (2005). "Gender differences in the job satisfaction of public employees: a study of Seoul Metropolitan Government, Korea”. Sex Roles. Vol. 52 Nos 9/10. pp. 667-81.

[11] Koyuncu, M., Burke, R. and Fiksenbaum, L. (2006). "Work experience and satisfaction of male and female professors in Turkey: signs of progress?". Equal Opportunities International. Vol. 25 No. 1. pp. 38-47.

[12] Kusluvan, S. and Kusluvan, Z. (2000). "Perceptions and attitudes of undergraduate tourism students towards working in the tourism industry in Turkey". Tourism Management. Vol. 21. pp. 251-69.

[13] Li, L. and Leung, R. (2001)."Female managers in Asian hotels: profile and career challenges". International Journal of Contemporary Hospitality Management.Vol. 13. pp. 189-96.

[14] Linz, S. (2003). "Job satisfaction among Russian workers". International Journal of Manpower. Vol. 24 No. 6. pp. 626-52.

[15] Locke, E. (1969). "What is job satisfaction?". Organizational Behavior and Human Performance. Vol. 4. pp. 309-36.

[16] McCuddy, M., Pinar, M. and Birkan, I. (2010). “Gender bias in managing human resources in the Turkish hospitality industry: is bias impacted by demographic context?". Proceedings of ASBBS.Vol. 17 No. 1. pp. 479-93.

[17] Mora, T. and Ferrer-i-Carbonell, A. (2009). "The job satisfaction gender gap among young recent university graduates: evidence from Catalonia". Journal of SocioEconomics.Vol. 38. pp. 581-9.

[18] Noe, F., Uysal, M. and Magnini, V. (2010). Tourist Customer Satisfaction: An Encounter Approach. Routledge. London.

[19] Okpara, J., Sqillace, M. and Erondu, E. (2005). "Gender differences and job satisfaction: a study of university teachers in the United States". Women in Management Review. Vol. 20 Nos 3/4. pp. 177-90.

[20] Okumus, F., Sariisik, M. and Naipaul, S. (2010). "Understanding why women work in five-star hotels in a developing country and their work-related problems". International Journal of Hospitality \& Tourism Administration. Vol. 11 No. 1. pp. 76-105.

[21] Pavesic, D. and Brymer, R. (1990). "Job satisfaction: what's happening to the young managers?". The Cornell Hotel and Restaurant Administration Quarterly. Vol. 30 No. 4. pp. 90-6.

[22] Pettijohn, C., Pettijohn, L. and Taylor, A. (2004). "The relationships between food service wait staff skills, satisfaction, commitment and their levels of customer orientation". International Journal of Hospitality \& Tourism Administration. Vol. 5 No. 2. pp. 43-59.

[23] Pinar, M., McCuddy, M., Birkan, I. and Kozak, M. (2011). "Gender diversity in the hospitality industry: an empirical study in Turkey". International Journal of Hospitality Management. Vol. 30.pp. 73-81.

[24] Rusbult, C., Farrell, D., Rogers, G. and Mainous, A. III (1988). "Impact of exchange variables on exit, voice, loyalty, and neglect: an integrative model of responses to declining job satisfaction". Academy of Management Journal. Vol. 31 No. 3. pp. 599-627.

[25] Ryan, C., Ghazali, H. and Mohsin, A. (2011). "Determinants of intention to leave a non-managerial job in the fast-food industry of West Malaysia", International Journal of Contemporary Hospitality Management. Vol. 23 No. 3.pp. 344-60.

[26] Schaap, J., Stedham, Y. and Yamamura, J. (2008). "Casino management: exploring gender-based differences in perceptions of managerial work". International Journal of Hospitality Management. Vol. 27. pp. 87-97.

[27] Schneider, B. and Snyder, R. (1975). "Some relationships between job satisfaction and organization climate". Journal of Applied Psychology. Vol. 60 No. 3. pp. 318-28.

[28] Spector, P.E. (1997). Job Satisfaction: Application, Assessment, Causes, and Consequences. Sage Publications. London.

[29] Szivas, E., Riley, M. and Airey, D. (2003). "Labor mobility into tourism: attraction and satisfaction", Annals of Tourism Research. Vol. 30 No. 1.pp. 64-76.

[30] Tuzun, I. (2009).“The impact of identification and commitment on job satisfaction: the case of a Turkish service provider". Management Research News. Vol. 32 No. 8. pp. 728-38. 
[31] Ward, M. and Sloane, P. (2000). "Non-pecuniary advantages versus pecuniary disadvantages; jobsatisfaction among male and female academics in Scottish universities". Scottish Journal of Political Economy. Vol. 47 No. 3. pp. 273-303.
[32] Yang, J. (2010). "Antecedents and consequences of job satisfaction in the hotel industry". International Journal of Hospitality Management.Vol. 29. pp. 609-19. 